\title{
Research on Abuse and Violence against the Elderly in a Family Setting
}

\section{Danijela Lahe*}

\begin{abstract}
The article calls for attention to the problem of violence and abuse of the elderly within their family, partnership, and relationships with relatives in the postmodern society. The outcomes of the research, carried out on a sample of the elderly people within different residence settings are presented. Results show that all kinds of violence and abuse are present in all kinds of settings, except in the residence with relatives, where sexual abuse was not noticed. Physical and sexual violence and abuse is mostly present in the households in which the elderly live with their partner, while psychical violence is present in the households with relatives. Material violence and abuse are present in case of elderly people who live alone. Both, men and women, experience most violence and abuse in their flats.
\end{abstract}

Key words: family, the elderly, violence and abuse, postmodern society.

\section{Introduction}

The problem of violence in the Slovene family seems to be more and more present, worth to be paid attention to and researched by the media and wider public policy. The reasons for this are the permanent warnings of the non-governmental organizations about the problems of violence in a family, statistical data which indicate increasing trends of the violence in private, higher level of public sensibility to this phenomenon, the regulation of the Criminal Law of the Republic of Slovenia (KZ-1, 2008), where violence in the family is considered as an act of violence, and last but not least important, the adoption of the Law on Prevention of violence in the family (ZPND Law on Prevention of Violence in Family, 2008).

Behavioral norms of the postmodern society, among which unfortunately are also ageism, sexism, and reconciliation with violence in society, are important factors in the occurrence of violence against the elderly. The elderly are often described as weak, helpless, dependent, in short, less worth to be paid attention to, from the state and their own family. The life quality of the elderly certainly does not depend on

${ }^{*}$ Danijela Lahe, Faculty of Arts, University of Maribor, Slovenia; danijela.lahe@uni-mb.si 


\section{Acta Technologica Dubnicae}

volume 1, 2011, issue 2

material conditions, but their safety and acceptance in the family, wider social environment and their psychosocial well-being are of great importance for their health as well.

In the sixties of the previous century, criminology became interested in violence against children. In the seventies criminology discovered women as the victims of violence and in the eighties the attention was paid to the elderly, who experienced violence within and outside the family.

Violence against the elderly in a family was first mentioned in 1975 in British research reviews (named "granny battering") (Baker, 1975; Burston, 1977). Abuse is a harsh reality for many old people however a lot of them do not want to admit openly that abuse is present and will be present in institutions and also in private family settings.

It is sensible to be mentioned in the very beginning that in the Slovene literature there are many examples where there is not possible to draw clear, undoubted border between violence and abuse. However, between these two concepts there are some essential differences. Violence is considered as any act against another person and against the will of that person. So, violence against the elderly includes all forms of behavior (spoken or acted) by the person who takes advantage of his/her superiority and affects the old person. It does not need to be a personal relationship among the perpetrator and the victim (Ramovš, 2007, pp. 90-91). According to the UN definition (ZN, 2002, 4) abuse is a single or repeated act, or inadequate behavior, happening in any relationship based on trust, which harms the old person and put her/him in danger. So, what makes the difference between the violence and abuse is a personal relationship between the victim and the perpetrator, when the act is being repeated. Regarding variety of unwanted behaviors and their similar, if not the same meaning, we decided to use both expressions - violence and abuse, together.

To prevent violence, it is necessary to recognise it. Therefore, we provide short descriptions of the most common typical forms of violence and abuse in a family the elderly are confronted with (Razboršek, 2002; Parker, 1999; ZN, 2002; Pentek, 2000).

Harm to the body or physical abuse: it means the usage of physical force on an old person, which may cause physical injuries, pains or defects. Psychical or mental abuse: causing suffering, emotional suffering or sadness. Moreover, dealing with the elderly like they are children, as well as prohibition of their contacts with family and friends, ignoring them or forcing them to be isolated from the social life, are all 


\section{Acta Technologica Dubnicae}

volume 1, 2011, issue 2

examples of psychical abuse. Negligence: rejection or unfulfilling any kind of obligations to the elderly, someone has to do for an old person. There are active and passive forms of negligence. Passive negligence means unintentional lack of care and help, caused by the lack of knowledge or information. In case of active negligence it is carried out intentionally/consciously. Financial or material abuse: is a form of illegal or irregular usage/exploitation of the old person's savings, possession or property: turning cheque into cash without permission, signature forging, theft of money or possession, signing of the document under the force or by playing trick on an old person (for example contract or will), rejection of the right to supervise his/her property, fraud, abuse of the position of a protector, caretaker or lawyer. Sexual abuse: it is an unwilling sexual act with an older person without their consent. Here is also included unwilling touching, forced nakedness and photo taking. Self negligence: it is a form of abuse when an old person neglects himself/herself, thus putting in danger his/her health and life. Medical abuse: this is a kind of abuse, when an old person is prescribed drugs which are not urgently needed (opiats, sedatives) or is unreasonably rejected further adequate therapy (too old for certain treatment). Aggressive testing which can put dying old people in danger is also considered to be medical abuse.

Besides all the mentioned forms of violence and abuse, it is significant that more types of abuse happen at the same time, they are intertwined and intensified (for example: exploitation, limitations, and at the end, violence). The elderly are, besides the mentioned violence, encountered with other negative phenomena: discrimination, human rights and freedom violation, inaccessibility of life supplies and other services.

Besides the signs of abuse, it is also important to recognise risk factors which can lead to violence in a family. Regardless, if the risk factors are the consequence of the environmental influence, psycho-physical or cultural and socio-economic influence, risk factors are present in family relationships (intimate, welfare, caring) where the elderly live at relatives' home or care homes. None of the places, unfortunately, offers a real home to the elderly. Instead of expected understanding, safety, shelter and warmth, they often encounter coldness, misunderstanding, bad relationships and conflicts (Felicijan, 2004, p. 13).

\section{Results of some studies on violence and abuse of the elderly in the world and Slovenia}

Violence against the elderly, which became of public interest much later than other types of violence, currently seem to be of interest of great number of researchers. Finally, current data are of exceptional value for each state which is willing to deal with this problem. At this point, it is sensible to warn about limitations on studying 


\section{Acta Technologica Dubnicae}

volume 1, 2011, issue 2

this phenomenon. Experts around the world give different definitions of an old age, what makes gaining the comparable empirical data difficult. The second limitation is, not precise and clear terminology regarding violence and abuse in the research of elderly people. Different terminology brings a lot of definitions, varying from study to study so much that their results are not comparable. Next problem is the use of different methods of collecting the data. Most researches were carried out on the basis of records on already reported abuse to the competent state institutions, or there were only assumptions about the possible abuses of the individuals (doctors, social workers, or randomly chosen people).

The beginning of the research of the extension of violence and abuse started in the world in the beginning of the nineties in the previous century. The first extensive American research was carried out by phone by K. A. Pillemer (cited in Filkenhor, 1988) in the area of Boston. They found out that 3.2\% of the surveyed experienced negligence, psychical or physical abuse, but they did not checked extension of material abuse, what is certainly the deficiency of the research. The Canadian research, four years later, included also material abuse into their research and revealed that material abuse was the most frequent type of abuse $(5 \%)$ of the elderly (Podnieks, 1992). In Great Britain in the same year there were psychically or physically abused or neglected $5 \%$ of the individuals older than 65 years of age (Bennett, 1992). Completely different methodology was applied in Finland, where the survey did not include the questions about the personal experience on violence and abuse only the questions about any knowledge of other people's experience (Ijas, 1992). Percentage of the abused was $5.7 \%$. Similar results were found in the Netherlands, $5.6 \%$ of the elderly up to 69 years of age was assumed to have experienced violence and abuse (Jonker, 1998).

No matter that the mentioned research was based on the relatively small samples and was methodically incomplete and not comparable, it provoked a few governmental institutions to start recognising the phenomenon. Results certainly confront us with the fact that violence and abuse are present and call for other experts/professionals to recognise the problem of the modern society as a global one.

According to the national study on violence and abuse of the elderly in the USA, based on the cases registered with the competent institutions, the authors assessed that in 1996 there were about half a million of people older than 60 years of age neglected or abused in a family setting (NEAIS, 1998). They also presumed that ratio of the registered and unregistered abuse was 1:5. Some experts also assess that there are around one to two million of the elderly Americans suffering from abuse (Dyer, 


\section{Acta Technologica Dubnicae}

volume 1, 2011, issue 2

2001). Even more frightening is the information that $84 \%$ abuses are not registered (NCEA, 2003).

The National Social Life, Health and Aging Project (NSHAP) is the first American national study based on the representative sample of the elderly. The respondents were asked about their experience with verbal, physical and material abuse in a family setting. Those who had experienced it were also asked who the perpetrators were. The sample comprised 3,005 older people, from 57 to 85 years of age. The study showed that $9 \%$ of respondents were abused verbally, $3.5 \%$ materially, and $1 \%$ physically (Waite, 2008).

\begin{tabular}{|c|c|c|c|}
\hline & $\begin{array}{c}\operatorname{VERBAL} \\
A B U S E(\%)\end{array}$ & $\begin{array}{l}\text { MATERIAL } \\
\text { ABUSE (\%) }\end{array}$ & $\begin{array}{l}\text { PHYSICAL } \\
\text { ABUSE (\%) }\end{array}$ \\
\hline \multicolumn{4}{|l|}{ Total sample } \\
\hline Number & 398 & 152 & 12 \\
\hline Spouse/partner & 26.2 & 9.6 & 19.6 \\
\hline Parent & 2 & 0 & 0 \\
\hline Child & 14.5 & 34 & 24.8 \\
\hline Other & 57.3 & 56.4 & 55.6 \\
\hline \multicolumn{4}{|l|}{ Partial sample $^{2}$} \\
\hline Number & 249 & 104 & 10 \\
\hline Spouse & 21.4 & 5.8 & 18.5 \\
\hline Ex spouse & 3.1 & 2.5 & 7.4 \\
\hline Partner & 1.6 & 1.6 & 4.7 \\
\hline Parent & 1.8 & 0 & 0 \\
\hline Father/mother-in-law & 0.3 & 0 & 0 \\
\hline Child & 13.7 & 35.7 & 21.3 \\
\hline Brother/sister & 7.6 & 12.3 & 0 \\
\hline Son/daughter-in-law & 5.1 & 2 & 12.5 \\
\hline Friend & 12.1 & 9.7 & 0 \\
\hline Neighbor & 5.5 & 2.2 & 0 \\
\hline Co-worker/chief & 15.7 & 5.6 & 0 \\
\hline Rest & 12 & 22.6 & 35.5 \\
\hline
\end{tabular}

Table 1 Abuse perpetrators (Waite, 2008, p. 254)

${ }^{1}$ Comprises questionnaire and a face-to-face interview.

${ }^{2}$ Comprises a face-to-face interview.

The data in Table 1 show the perpetrators' relation to the victims, who experienced verbal, material or physical abuse. According to the data from the first part of Table 


\section{Acta Technologica Dubnicae}

volume 1, 2011, issue 2

1, we can find out that the most frequent perpetrators are not the members of the nuclear family. There was a question about the other members of the family. Therefore, the authors carried out a face-to-face interview, where the respondents mentioned other perpetrators within the extended family. The other perpetrators are shown in the second part of the table. It is obvious that the perpetrators are brothers and sisters and son/daughter-in laws. Similar data were gained by M. Arai (2006), who found out that parents who live with their adult son and his wife experience more abuse in the relation with a daughter-in law.

In 2007 a research named "Health and Long-Term Care in the Europian Union" (Special Eurobarometer 283, 2007), comprising the sample of 28,660 Europeans older than 15 years of age was carried out by EU. All EU state members (EU27) and two states-candidates (Croatia and Turkey) took part in the research. The respondents were, among other issues, assessing also the extension and characteristics of violence against the elderly on the basis of their own presumptions. Generally speaking, the highest risk factors of abuse among the EU state members, besides Turkey, exist in Romania and Greece. At the bottom of the scale is Sweden, with the lowest percentage of different types of violence against the elderly. Considering only the negligence of the elderly, Malta steps out with a positive trend (Special Eurobarometer 283, 2007).

It was not until recently that the violence and abuse of the elderly were discovered in Slovenia. The first research in this field was made by the Anton Trstenjak Institute in 2003. The research was carried out among the subscribers of the journal "Quality old age" and the volunteers of intergeneration societies for quality old age. The aim of the research was to gain as much information as possible and to warn the public about the abuse of the elderly in Slovenia.

In 2004, the Government's Office for Equal Opportunities conducted a research "Violence against the Elderly", in which 43 centres for social work, 23 community services and 187 pensioners' societies took part. The research showed that older women are the victims of different types of violence more often than the older men. The most frequent types of violence are the psychical and physical abuse, most often caused by their partners.

It has to be said that in Slovenia there are very few professionals who are studying the issues of violence against the elderly within the family. There are very few studies on the specific types of violence, and even those are geographically, time, content or disciplinary limited. 


\section{Acta Technologica Dubnicae}

volume 1, 2011, issue 2

We have the analyses of the legislative regulations of the family violence, the data of the centres for social work in the form of case studies, the data which point out the aspects of criminality from the Ministry for domestic affairs or the police, on disposal. At the same time we are confronted with the lack of more complex sociological studies, which would register social background and causes of the family violence, its nature and prevalence.

The only extensive empirical research about the violence in a family, ordered by the Ministry of Work, Family and Social Affairs, was conducted by the Scientific and Research Centre of the Koper University in Primorska and the Faculty for Social Sciences in 2005. The opinion poll "Violence in Families" (Simčič, 2006) at representative sample $(n=1006)$ of off age population of the Republic of Slovenia was prepared and carried out within the project "The Analysis of the Family Violence in Slovenia - Suggestions of Preventive Measures". The goal of this opinion poll was a holistic analysis and interpretation of the existing state and social climate and attitudes to the questions tackling the issues of violence in a family. The analysis also contained the cluster of questions checking familiarity of the respondents with the phenomenon of violence against the elderly in families. When asked if they knew family in which violence was carried out with the old person, most respondents, $86.4 \%$, answered "no", $13.6 \%$ knew one, two or more such families. Most often were the cases of psychical violence $(40 \%)$, followed by the negligence $(21 \%)$, physical violence (19\%), economical (18\%) and sexual violence $(2 \%)$.

\section{Empirical research}

The objective of our research was to present and point to the actual phenomenon of the violence and abuse of the elderly and indirectly to the need of the holistic approach and solution of the problem, and at the same time to present an empirical picture of the extension and structure of the violence and abuse of the elderly.

Our research was based on two hypotheses predicting:

H1: that all forms of violence and abuse are present in all kinds of living environments and that the abuse occurs mainly in the households where an old person lives with a partner;

H2: that the violence and abuse happen mainly in the victim's home setting.

Research methods: the basic research methods used were the descriptive and causal non-experimental method of the empirical sociological research. 


\section{Acta Technologica Dubnicae}

volume 1, 2011, issue 2

Survey sampling: the sample consisted of 300 individuals 65 years of age and older, living in Maribor area and its outskirts, alone, in their own household with a partner, with relatives, and at care homes: Danica Vogrinec Maribor (unit Pobrežje and unit Tabor), Sony Home, Home for the Elderly - Community of Tezno and Lambrecht's Home Slovenske Konjice.

Data collection and processing methods: the data were acquired by a probe and questionnaires. The questionnaire consisted of 23 open or closed questions. There were 340 surveyed individuals. 300 properly filled-in questionnaires were analysed. Three essential measurement characteristics of the questionnaire were considered: validity, objectivity and reliability.

The collected data were processed by the statistical program SPSS. The gained empirical data were processed by a multivariate analysis, using following statistical tools: frequent dispersion, median, standard deviation of the cross table and correlation coefficients.

We also considered limitations and presumptions: the research was based on the common presumption of scientific recognition and specific limitation of the questionnaire because of some similar indicators between the psychical violence, abuse and negligence. The latter one was not included into the research, and some of the respondents did not fill in the questionnaire considering the phenomenon as a taboo topic.

\subsection{Results and interpretation}

The sample was made of $24 \%$ male and $76 \%$ female respondents. More than a half of the respondents lived in their domestic environment: $18 \%$ lived in their own household, $21.7 \%$ lived together with a partner in their own household, and $17.7 \%$ lived together with their relatives. Other individuals were care home residents $(42.7 \%)$. The marital status data showed that more than a half of the respondents $(56.3 \%)$ were widows or widowers, $26 \%$ were married, $9.3 \%$ single, $6.3 \%$ divorced or lived separately, and $1.7 \%$ were unmarried.

Before analysing the presence of the single form of violence and abuse, it should be mentioned that the variables indicating a single kind of violence and abuse were gained by adding values to indicators and the sum was divided by the number of added indicators. The value indicators were: 1 - never, 2 - sometimes, 3 - often, 4 regularly. The higher is the mean, the more often the violence happens. 


\begin{tabular}{||l|l|l|l|l|l||}
\hline \hline Type of violence & $n$ & minimum & maximum & median & $\begin{array}{l}\text { standard } \\
\text { deviation }\end{array}$ \\
\hline Psychical violence & 300 & 1.00 & 3.20 & 1.588 & 0.469 \\
\hline Material violence & 300 & 1.00 & 3.00 & 1.327 & 0.436 \\
\hline Physical violence & 300 & 1.00 & 2.40 & 1.183 & 0.308 \\
\hline Sexual violence & 300 & 1.00 & 2.67 & 1.109 & 0.300 \\
\hline
\end{tabular}

Table 2 Frequency of the types of violence and abuse

According to the gained empirical data, it was found out that the elderly were mostly exposed to psychical violence and abuse, as the estimated value of the median was 1.588 , followed by material violence and abuse 1.327 , physical violence and abuse 1.183 and sexual violence and abuse 1.109. Out of the calculated median it is presumable that all types of violence and abuse are present in all types of living settings. This is verified by statistically significant difference $(\mathrm{p}=0.00)$ in all types of violence.

\begin{tabular}{||l|l|l|l|l|l||}
\hline \multirow{2}{*}{ Type of violence } & \multirow{2}{*}{$n$} & \multirow{2}{*}{ median } & \multirow{2}{*}{$\begin{array}{l}\text { st. } \\
\text { deviation }\end{array}$} & \multicolumn{2}{|l||}{ test value is 1} \\
\cline { 5 - 7 } & & & t-test & sig. \\
\hline psychical violence & 300 & 1.5883 & 0.46943 & 21.708 & 0.000 \\
\hline material violence & 300 & 1.3267 & 0.43572 & 12.986 & 0.000 \\
\hline physical violence & 300 & 1.1827 & 0.30770 & 10.282 & 0.000 \\
\hline sexual violence & 300 & 1.1089 & 0.29987 & 6.289 & 0.000 \\
\hline
\end{tabular}

Table 3 Structure of the presence of violence and abuse in all kinds of living settings

\begin{tabular}{|c|c|c|c|c|c|}
\hline \multirow{2}{*}{$\begin{array}{l}\text { Type of violence in case of } \\
\text { single life in one's own } \\
\text { household }\end{array}$} & \multirow[b]{2}{*}{$n$} & \multirow[b]{2}{*}{ median } & \multirow[b]{2}{*}{$\begin{array}{l}\text { st. } \\
\text { deviation }\end{array}$} & \multicolumn{2}{|c|}{ test value is 1} \\
\hline & & & & $t$-test & sig. \\
\hline psychical violence & 54 & 1.6926 & 0.49558 & 10.270 & 0.000 \\
\hline material violence & 54 & 1.5586 & 0.58828 & 6.978 & 0.000 \\
\hline physical violence & 54 & 1.2704 & 0.41145 & 4.829 & 0.000 \\
\hline sexual violence & 54 & 1.1728 & 0.44269 & 2.869 & 0.006 \\
\hline \multirow{2}{*}{$\begin{array}{l}\text { type of violence in case of life } \\
\text { with a partner in one's own } \\
\text { household }\end{array}$} & \multirow[b]{2}{*}{$n$} & \multirow[b]{2}{*}{ median } & \multirow{2}{*}{$\begin{array}{l}\text { st. } \\
\text { deviation }\end{array}$} & \multicolumn{2}{|c|}{ test value is 1} \\
\hline & & & & $t$-test & sig. \\
\hline psychical violence & 65 & 1.6354 & 0.48844 & 10.488 & 0.000 \\
\hline material violence & 65 & 1.3513 & 0.45465 & 6.229 & 0.000 \\
\hline
\end{tabular}




\begin{tabular}{||l|l|l|l|l|l||}
\hline physical violence & 65 & $\mathbf{1 . 3 0 1 5}$ & 0.39548 & 6.147 & 0.000 \\
\hline sexual violence & 65 & $\mathbf{1 . 2 3 5 9}$ & 0.38964 & 4.881 & 0.000 \\
\hline $\begin{array}{l}\text { type of violence in case of life } \\
\text { with relatives }\end{array}$ & \multirow{2}{*}{$n$} & \multirow{2}{*}{ median } & \multirow{2}{*}{$\begin{array}{l}\text { st. } \\
\text { deviation }\end{array}$} & \multicolumn{2}{|l||}{ test value is 1} \\
\cline { 5 - 7 } & & & t-test & sig. \\
\hline psychical violence & 53 & $\mathbf{1 . 7 6 2 3}$ & 0.51300 & 10.818 & 0.000 \\
\hline material violence & 53 & 1.4308 & 0.34504 & 9.090 & 0.000 \\
\hline physical violence & 53 & 1.2340 & 0.26234 & 6.493 & 0.000 \\
\hline sexual violence & 53 & 1.0314 & 0.14999 & 1.526 & $\mathbf{0 . 1 3 3}$ \\
\hline $\begin{array}{l}\text { type of violence in case of care } \\
\text { home residence }\end{array}$ & \multirow{2}{*}{$n$} & average & \multirow{2}{*}{$\begin{array}{l}\text { st. } \\
\text { deviation }\end{array}$} & test value is 1 \\
\hline psychical violence & 128 & 1.4484 & 0.38760 & 13.090 & 0.000 \\
\hline material violence & 128 & 1.1732 & 0.31331 & 6.253 & 0.000 \\
\hline physical violence & 128 & 1.0641 & 0.13959 & 5.192 & 0.000 \\
\hline sexual violence & 128 & 1.0495 & 0.16779 & 3.336 & 0.001 \\
\hline
\end{tabular}

Table 4 The structure of the violence and abuse occurrence in various settings

The gained empirical data show that all types of violence and abuse are present in each type of setting, however, the statistical correlation shows that the sexual violence is not present in case of the residence with relatives, i.e. it is not significant $(\mathrm{p}=0.133)$.

We found out that all types of violence and abuse are present at all living settings, except the setting with relatives where the median is not significant. Therefore, we cannot claim that the violence is present in this setting. It is necessary to point out a piece of information about the median experience of sexual violence and abuse, which is, among all types of residence, the highest one at one's own household and life with a partner.

On the basis of the type of living setting of the respondents, it was found out that there were significant differences in the presence of all types of violence and abuse. Physical and sexual violence and abuse were most frequently present in the household in which the elderly live together with their partners (1.3015 and 1.2359), while on average, there is most of the psychical violence and abuse in the joint households with relatives (1.7623) and there is most of the material violence and abuse among the elderly who live alone (1.5586). The data also showed that most of the violence and abuse happen in domestic environment. Therefore, the $\mathrm{H} 1$ is completely rejected. 


\begin{tabular}{|c|c|c|c|c|c|c|c|}
\hline \multicolumn{7}{|c|}{ Where the type of violence and abuse were experienced } \\
\hline & & $\begin{array}{c}\text { in my } \\
\text { flat }\end{array}$ & $\begin{array}{c}\text { in the } \\
\text { relatives' flat }\end{array}$ & $\begin{array}{c}\text { at care } \\
\text { home }\end{array}$ & other & together \\
\hline gender & male & number & 35 & 11 & 9 & 3 & 58 \\
\hline & & share & $60.3 \%$ & $19.0 \%$ & $15.5 \%$ & $5.2 \%$ & $100.0 \%$ \\
\hline & & $\begin{array}{c}\text { share } \\
\text { altogether }\end{array}$ & $13.8 \%$ & $4.3 \%$ & $3.5 \%$ & $1.2 \%$ & $22.8 \%$ \\
\hline & female & number & 93 & 17 & 73 & 13 & 196 \\
\hline & & share & $47.4 \%$ & $8.7 \%$ & $37.2 \%$ & $6.6 \%$ & $100.0 \%$ \\
\hline & & $\begin{array}{c}\text { share } \\
\text { altogether }\end{array}$ & $36.6 \%$ & $6.7 \%$ & $28.7 \%$ & $5.1 \%$ & $77.2 \%$ \\
\hline together & & number & 128 & 28 & 82 & 16 & 254 \\
\hline & & share & $50.4 \%$ & $11.0 \%$ & $32.3 \%$ & $6.3 \%$ & $100.0 \%$ \\
\hline & $\begin{array}{c}\text { share } \\
\text { altogether }\end{array}$ & $50.4 \%$ & $11.0 \%$ & $32.2 \%$ & $6.3 \%$ & $100.0 \%$ \\
\hline
\end{tabular}

Table 5 Share of the locality of violence and abuse experience

It is obvious that the male, as well as the female respondents experienced most of violence and abuse at their homes (50.4\%). 11\% of the respondents experienced violence and abuse in their relatives' flat, $32.3 \%$ at care home, $6.3 \%$ elsewhere (in the street, in the yard...). Thus the $\mathrm{H} 2$ is confirmed.

\section{Concluding remarks}

Violence and abuse of the elderly is a serious, but unfortunately a very frequent problem in a family, community and in care home settings.

Respect for human rights is one of the most important criteria for the definition of a country's democracy. The elderly should have completely equal rights as other age groups, but unfortunately, their rights are often overlooked or not completely recognised. If we want to ensure a decent life to the elderly in a democratic state, we have to respect the human rights and increase the social sensibility to violence and abuse in a family. Informing and public awareness are the basic parts of prevention, along with the irreplaceable roles of the education system, bringing up and media.

At the same time it is necessary to continuously develop preventive social work activities in the societies of the elderly and other non governmental organisations, which unite older citizens. The meetings within intergeneration programs for quality aging are an excellent possibility for elderly people to speak about their dark sides of life in confidence. In the holistic approach to the problem of violence and abuse of the elderly an in-depth analysis and interpretation of the actual state are important. Since the current data are of exceptional importance for each state which has an intention to 


\section{Acta Technologica Dubnicae}

volume 1, 2011, issue 2

deal with this problem successfully. It is also meaningful to mention some limitations which make comparison of the data regarding the research of this phenomenon impossible. Preparation of a unique questionnaire with comparable scales for violence and abuse sensitivity testing, presuming that it contains all types of violence and abuse of the elderly, would be of great help at least in the area of the European Union.

In conclusion, it must be said that no one is allowed to close their eyes to the distress of a family. Each citizen is obliged, according to their abilities, to contribute to the decrease of the phenomenon of violence and abuse of the elderly in a family and thus to help victims experience a ray of hope.

\section{References}

ARAI, M.: Elder abuse in Japan. In Educational Gerontology, 32, 2006, pp. 13-23.

BAKER, A. A.: Granny Battering. In Modern Geriatrics, 8, 1975, pp. 20-24.

BENNETT, G. C. J.: Elder Abuse in Britain. In British Medical Journal, 303, 1992, pp. 998-999.

BURSTON, G.: Do your elderly patient live in fear of being battered? In Modern Geriatrics, 7, 1977, pp. 54-55.

DYER, C. B.: Quantifying the problem of elder abuse and neglect in adults: Analysis of a statewide database. In Journal of the American Geriatrics Society vol. 49, 2001, n. 1, pp. 45-48.

FELICIJAN, S.: Dogaja se njej in dogaja se mnogim: ne bi se smelo: raziskava o zlorabi starih ljudi v Sloveniji. In Kakovostna starost, vol. 7, 2004, n. 1, pp. 12-20.

FINKELHOR, D.: The prevalance of elder abuse: A random sample survey. In The Gerontologist, vol. 28, 1998, n. 1, pp. 51-57.

IJAS, M. L.: Abuse in old age: Epidemiological data from Finland. In Journal of Elder Abuse and Neglect vol. 4, 1992, n. 3, pp. 1-18.

JONKER, C.: Elder abuse in the community: Prevalance and consequences. In Journal of the American Geriatrics Society, 46, 1998, pp. 885-888.

Kazenski zakonik 1 (KZ-1), 2008. Uradni list RS, št. 55/2008.

National Center of Elder Abuse (NCEA), 2003.

Retrieved 15. 9. 2008 from: http://www.ncea.aoa.gov/ncearoot/Main_Site/index.aspx.

National Elder Abuse Incidence Study (NEAIS): final report. (1998). Washington: Administration for Children and Families and the Administration on Aging. Retrieved 15.1.2009 from http://www.aoa.gov/abuse/report.

PARKER, J.: Elder abuse and older men: towards and understanding. COEStrasbourg, 1999. 


\section{Acta Technologica Dubnicae}

volume 1, 2011, issue 2

PENTEK, M.: Nasilje, zloraba in starejši ljudje. In Nasilje, zloraba in starejši ljudje. Otočec: Gerontološko društvo Slovenije, 2000.

PODNIEKS, E.: National Survey on Abuse of the Elderly in Canada. In Journal of Elder Abuse and Neglect, vol. 41, 1992, n. 1-2, pp. 5-58.

RAMOVŠ, K.: Odločen "ne" nasilju in zlorabam. In Praktični vodnik za upokojence: pravice, možnosti, priložnosti. Ed. M. Starič. Ljubljana: Založba Maks Viktor, pp. 90-93.

RAZBORŠEK, V.: Oblike zlorabljanja starejših ljudi. In Kakovostna starost, vol. 5, 2002, n. 1-2, pp. 31-35.

Raziskava o nasilju nad starejšimi, 2004.

Retrieved 28. 11. 2008 from http://www.uem.gov.si.

SIMČIČ, B.: Nasilje $v$ družini: pregled dobrih praks in priporočila. Koper: Znanstveno-raziskovalno središče Koper, 2006.

Special Eurobarometer 283: Health and Long-Term Care in the Europian Union, 2007. Retrieved 5. 5. 2009 from

http://ec.europa.eu/public_opinion/archives/ebs/ebs_283_en.pdfZakon $o$ preprečevanju nasilja $v$ družini (ZPND), 2008.

Uradni list RS, št. 16/2008.

WAITE, L. J.: Elder Mistreatment in the United States: Prevalance Estimates From a Nationally Representative Study. In The Journals of Gerontology: Psychological Sciences and Social Sciences, vol. 63, 2008, no. 4, pp. 248-254.

ZN Abuse of older persons: recognizing and responding to abuse of older persons in a global context - Report of the Secretary General. Economic and Social Council. UN E/CN.5/2002/PC/2. 